\title{
Analisis Hubungan Panjang Berat Pada Ikan Hermaphrodit: Kerapu Sunu (Plectropomus leopardus) dan Kerapu Macan (Epinephelus fuscoguttatus)
}

\author{
Haris Setiawan $^{1 *}$, Achmad Fahrudin', Mohammad Mukhlis Kamal² \\ ${ }^{1}$ Program Studi Pengelolaan Sumberdaya Pesisir dan Lautan Institut Pertanian Bogor, Indonesia; \\ ${ }^{2}$ Departemen Manajemen Sumberdaya Perairan, Fakultas Perikanan dan Ilmu Kelautan, IPB;
}

\author{
Riwayat artikel \\ Received : 08 Mei 2019 \\ Revised : 08 Juli 2019 \\ Accepted : 09 Juli 2019 \\ Published : 14 Agustus 2019 \\ *Corresponding Author: \\ Haris Setiawan, \\ Program Pengelolaan \\ Sumberdaya Pesisir dan Laut, \\ Institut Pertanian Bogor; \\ Email: \\ harissetiawan806@yahoo.com
}

\begin{abstract}
Abstrak : Penelitian ini bertujuan untuk mengeksplorasi hubungan panjang berat dua spesies ikan kerapu hermafrodit, yaitu kerapu sunu (Plectropomus leopardus) dan kerapu macan (Ephinephelus fuscoguttatus). Sebanyak 1.263 individu ikan yang terdiri dari 609 dan 654 spesies pertama dan kedua, masingmasing dikumpulkan dari perairan Wangi-Wangi dan Karang Kaledupa Taman Nasional Wakatobi selama September 2018 hingga Februari 2019. Ikan dikumpulkan secara acak yang merupakan hasil tangkapan pancing dan tombak. Hasil kedua spesies menunjukkan pola pertumbuhan alometrik ( $\mathrm{p}$ $<0,01$ untuk keduanya) di mana nilai b masing-masing adalah 2,46 dan 2,73. Berdasarkan koefisien korelasi $\left(\mathrm{R}^{2}\right)$, ditemukan bahwa variasi berat mampu menjelaskan $90 \%$ lebih panjang tubuh ikan. Berdasarkan panjang ikan saat tertangkap dan panjang pertama kali matang gonad, ditemukan bahwa betina P. leopardus sebagian besar ditangkap sebelum matang gonad (> 70\%), sedangkan E. fuscoguttatus untuk kategori yang sama berada pada persentase yang lebih rendah $(<50 \%)$. Langkah-langkah pengelolaan pada spesies hermafrodit dapat difokuskan pada proporsionalitas antara betina dan jantan terhadap keberhasilan reproduksi.
\end{abstract}

Kata Kunci : Panjang Berat, E. fuscoguttatus, P. leopardus

\begin{abstract}
The present research was aimed to explore the length-weight relationship-based growth of two hermaphrodite groupers, leopard coral grouper (Plectropomus leopardus) and tiger grouper (Ephinephelus fuscoguttatus). A total of 1,263 individual fishes comprising 609 and 654 individuals of these two species respectively, were collected from WangiWangi and Kaledupa reef in Wakatobi National Park from September 2018 to February 2019. Fish were randomly sampled from catches that used hook-andlines and spears. The results found that both species follow allometric growth patterns ( $\mathrm{p}<0,01$ for both) of which $\mathrm{b}$ values were, respectively, 2,46 and 2,73. Based on coefficient correlation $\left(\mathrm{R}^{2}\right)$, it was found that weight variability is able to explain more than $90 \%$ of length. By comparing length at catch and length at first maturity, it was found that females of $P$. leopardus were largely caught at pre-mature stage $(>70 \%$ ), while for E. fuscoguttatus $<50 \%$ of females were pre-mature. We suggest that management measures for hermaphrodite species should focus on the proportionality between females and males towards their reproductive success.
\end{abstract}

Keywords : Length-weight relationship, E. fuscoguttatus, P. leopardus

\section{Pendahuluan}

Ikan kerapu sunu (P. leopardus) dan kerapu macan (E. fuscoguttatus) merupakan anggota dari marga Serranidae yang pola reproduksinya bersifat hermaprodit protogini, yaitu gonad sebagai organ reproduksi mengalami perubahan dari fase betina ke jantan (Sadovy dan Colin, 1995; Widodo, 2006). Hasil penelitian menunjukkan bahwa perubahan kelamin pada kedua spesies secara berrurut terjadi pada ukuran $43 \mathrm{~cm}$ (Binohlan, 2010), dan $42 \mathrm{~cm}$ (Elevati dan Aditya, 2001). Selanjutnya Binohlan (2010) menjelaskan bahwa kecepatan pertumbuhan kedua spesies ini lambat, yang merupakan salah satu ciri utama ikan berumur panjang. Ikan kerapu macan dapat mencapai umur 40 tahun dan memiliki panjang maksimum yang pernah diketahui 
berukuran sepanjang $1200 \mathrm{~mm}$. Adapun usia ikan kerapu sunu dapat mencapai 26 tahun dengan panjang maksimum $1200 \mathrm{~mm}$.

Ikan yang memiliki pertumbuhan lambat, usia yang panjang, dan bersifat hermaphrodit memiliki risiko tangkap lebih (overfishing) dan ancaman kepunahan yang lebih tinggi akibat tekanan eksploitasi. Beberapa peneliti (Sadovy, 2005; Tuya at al., 2006).) menyatakan bahwa potensi ikan kerapu di Indonesia telah mengalami penurunan populasi akibat tekanan penangkapan. Permintaan pasar yang terus meningkat dan nilai ekonomis yang tinggi telah mendorong peningkatan intensitas penangkapan, sehingga sumberdaya ikan kerapu rentan terhadap ancaman kepunahan (Cheung et al., 2013; Putri et al., 2013; Theresia et al., 2013). Selain hal tersebut, aktivitas penangkapan dengan menggunakan alat tangkap yang tidak ramah lingkungan masih terjadi, seperti penggunaan bius, bom dan penggunaan alat bantu pernapasan (kompesor). Penggunaan alat tangkap tersebut dapat merusak ekosistem terumbuh karang yang merupakan habitat ikan. Pontoh (2011) melaporkan bahwa hasil penelitian di perairan desa Araka dan Wawontulap menunjukan kerusakan 25\% tutupan terumbu karang disebabkan penangkapan ikan menggunakan bom (Sala et al., 2011).

Perairan Wangi-Wangi dan Kaledupa merupakan salah satu perairan zona pemanfaatan bahari Taman Nasional Wakatobi (TNW). Sumber daya perikanan kerapu di perairan ini merupakan target utama penangkapan, termasuk kedua jenis tersebut (Tadjuddah et al., 2013). Ukuran ikan yang ditangkap umumnya disesuaikan dengan permintaan pasar yaitu ikan dengan bobot antara 500->1000 gram. Bilamana dikonversi ke panjang, maka ikan-ikan tersebut lebih kecil dari ukuran pertama matang gonad $\left(\mathrm{L}_{\mathrm{m}}\right)$. Sehingga Jika tidak ada pengelolaan penangkapan, maka ancaman kepunahan sumberdaya ikan kerapu sangat nyata.

Pengelolaan diperlukan informasi biologi, diantaranya adalah hubungan panjang berat. Hubungan panjang berat ikan (LWR) adalah sebuah pendekatan manajemen perikanan yang penting dalam biologi perikanan dan penilaian stok di perairan yang dapat menentukan struktur umur ikan (Ayoade dan Akulala, 2007). Selain itu hubungan panjang berat dapat menjelaskan perubahan ukuran individu, menunjukkan pola pertumbuhan organisme, mendapatkan indeks kondisi fisik populasi, umur ikan, mortalita dan mengevaluasi kualitas habitat (Albuquerque et al., 2009).

Adebiyi (2013) melaporkan hasil penelitian di pantai Lagon Nigeria bahwa ekploitasi ikan yang berlebihan dapat menyebabkan dampak negative pada populasi sehingga hubungan panjang berat ikan dapat digunakan untuk menilai stok berbasis panjang dalam pengelolaan perikanan.

Pengelolaan perikanan berbasis panjang belum terjadi dengan baik di perairan Taman Nasional Wakatobi karena aktifitas penangkapan ikan kerapu cukup tinggi terjadi pada ukuran $<42 \mathrm{~cm}$ (fase reproduksi betina). Penangkapan tersebut dapat menyebabkan tekanan dalam populasi sehingga perlu dilakukan penelitian hubungan panjang berat kerapu macan (E. fuscoguttatus) dan kerapu sunu ( $P$. leopardus).yang menjelaskan perubahan ukuran individu dan pertumbuhan organisme. Penelitian ini juga dibutuhkan untuk mengetahui pengelolaan perikanan kerapu berbasis ukuran tangkapan untuk mengurangi proporsi ikan yang tertangkap.

\section{Bahan dan Metode}

\section{Lokasi Penelitian}

Penelitian ini dilakukan di perairan perairan Wangi-Wangi dan Kaledupa Taman Nasional Wakatobi selama September 2018 sampai Februari 2019. Lokasi penangkapan ikan kerapu merupakan habitat terumbu karang. Aktifitas penangkapan terkonsentrasi di perairan karang Kapota dan karang Kaledupa. Hal ini disebabkan jumlah spesies target kerapu lebih beragam dan hasil tangkapan per trip nya lebih banyak dibandingkan dengan lokasi lainnya di perairan Wangi-Wangi dan Kaledupa (Gambar 1).

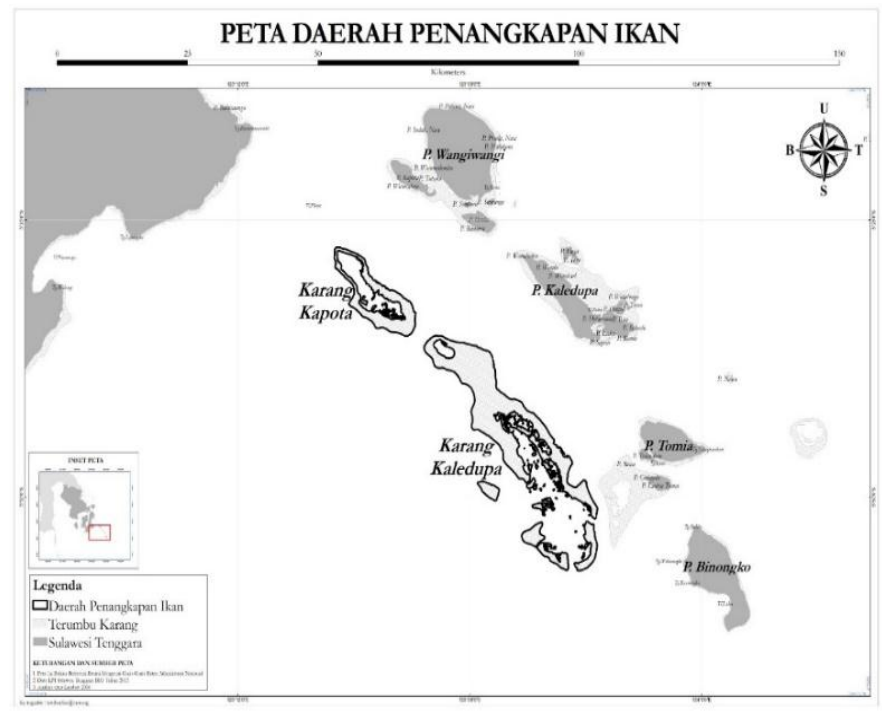

Gambar. 1. Lokasi Penangkapan dan pengumpulan sampel ikan kerapu

Ikan kerapu ditangkap dengan pancing ulur ukuran 6-7 cm, pancing intip ukuran 6-7 cm, pancing kedo-kedo (pancing tonda) ukuran $7-8 \mathrm{~cm}$ dan tombak ukuran 1 meter. Total rata-rata hasil tangkapan per bulan untuk ikan kerapu macan adalah $200 \mathrm{~kg}$, dan ikan kerapu sunu 300 $\mathrm{kg}$.

\section{Pengukuran Panjang Berat Ikan}

Pengukuran panjang berat ikan bertujuan untuk mengetahui variasi berat dan panjang tertentu dari ikan secara individual atau kelompok-kelompok individu sebagai suatu petunjuk tentang kegemukan, kesehatan, produktifitas dan kondisi fisiologis termasuk perkembangan gonad (Richter, 2007; Blackweel et al., 2000). Panjang ikan diukur dengan menggunakan mistar 
berketelitian $0,1 \mathrm{~cm}$ dan berat ikan ditimbang dengan timbangan berketelitian 0,01 gram. Hubungan panjang berat ikan dihitung dengan menggunakan persamaan De Robert dan William (2008).

Dimana:

$$
W=a L^{b}
$$

$\mathrm{W}$ adalah berat tubuh (gram)

$\mathrm{L}$ adalah panjang total ikan ( $\mathrm{mm})$

a dan $b$ adalah konstatnta.

$\begin{array}{rlr}\text { Persamaan } & \text { hubungan panjang } & \text { berat } \\ \text { ditranformasikan kedalam logaritma dan } & \text { akan }\end{array}$ memperoleh persamaan:

$$
\log W=\log a+b \log L
$$

Hasil dari perhitungan menggunakan persamaan tersebut akan diperoleh nilai $b<3$ atau nilai $b>3$ yang berarti pertumbuhan ikan bersifat allometrik atau pertumbuhan berat dan panjang tidak sebanding. Jika nilai $\mathrm{b}=3$ berarti pertumbuhan berat dan panjang ikan sebanding dan disebut isometrik (Muchlisin at al., 2010). Untuk mengkaji nilai b dilakukan uji t.

$$
t_{\text {hitung }}=\left|\frac{b-b_{0}}{s b_{0}}\right|
$$

Pengambilan keputusan terhadap hipotesis ditentukan dengan membandingkan $\mathrm{t}$ hitung dan $\mathrm{t}$ tabel pada selang kepercayaan $95 \%$. Jika nilai $t$ hitung $<t$ tabel pada selang maka keputusannya adalah terima Ho (Walpole, 1995).

Untuk melihat aktifitas perikanan tangkap dikaitkan dengan praktek pengelolaan saat ini, maka setiap panjang ikan dibandingkan dengan ukuran maksimum (www.fishbase.org) dan ukuran pertama kali memijah untuk kedua jenis kerapu tersebut (Binochlan, 2010; Elevati dan Aditya, 2001).

\section{Hasil dan Pembahasan}

\section{Hubungan Panjang Berat}

Total sampel ikan kerapu sunu (P. leopardus) dan ikan kerapu macan (E. fuscoguttatus) yang diukur 609 dan 654 ekor. Ukuran ikan kerapu sunu yang tertangkap 180$670 \mathrm{~mm}$ (rerata $452 \mathrm{~mm}$ ) dan 150-3700 gram. Untuk ikan kerapu macan ukuran yang tertangkap mulai dari 240-970 $\mathrm{mm}$ (rerata $419 \mathrm{~mm}$ ) dan 200-12400 gram. Secara umum ukuran ikan kerapu macan (E. fuscoguttatus) lebih besar dibandingkan dengan kerapu sunu (P. leopardus). Selain itu proporsi ikan kerapu sunu ( $P$. leopardus) yang tertangkap didominasi fase reproduksi betina. Berbeda halnya dengan proporsi ikan kerapu macan ( $E$. fuscoguttatus) yang didominan fase reproduksi jantan. (Gambar 2).
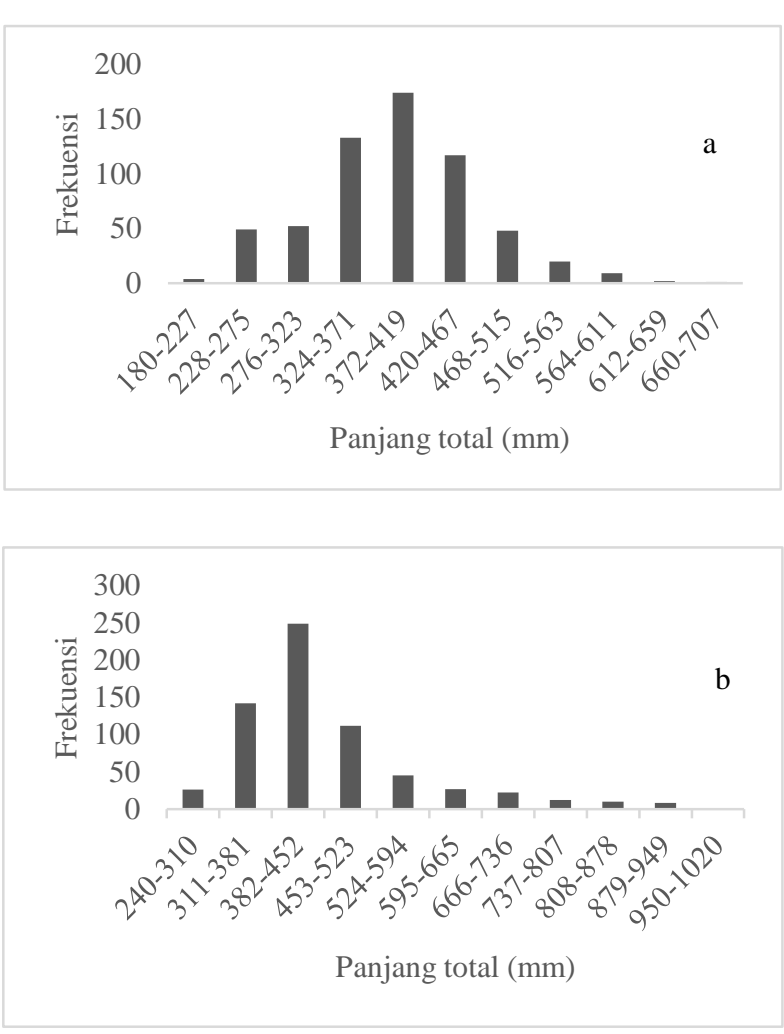

Gambar. 2. Distribusi frekuensi Panjang total $P$. leopardus (a); Distribusi frekuensi Panjang total E. fuscoguttatus (b)

Hasil analisis LWR menujunkan bahwa nilai $b$ ikan kerapu sunu (P. leopardus) 2,46 dan ikan kerapu macan (E. fuscoguttatus) 2,73 (Gambar 3 ). Hasil uji-t menunjukan bahwa ikan kerapu sunu tidak menunjukan perbedaan yang signifikan $(\mathrm{P}>0,05)$, Sedangkan ikan kerapu macan menunjukan perbedaan yang signifikan $(\mathrm{P}<0,05)$. Hal ini menunjukan pertumbuhan allometrik negatif yang berarti bahwa pertumbuhan panjang dan berat tidak sebanding (Muchlisin at al., 2010). Penelitian yang dilakukan Ramadani et al., (2017) di Pulau Aceh melaporkan bahwa ikan kerapu sunu ( $P$. leopardus) dan kerapu macan (E. fuscoguttatus) menunjukan pertumbuhan alometrik negatif.

Pola pertumbuhan allometrik negatif dapat disebabkan penggunaan alat tangkap yang tidak ramah lingkungan seperti penggunaan bius, kompresor sebagai alat bantu dan bahan peledak yang dapat mempengaruhi populasi ikan (Sartika, 2003). Selain itu faktor-faktor yang mempengaruhi ukuran pertumbuhan yaitu kematangan seksual, makanan, habitat atau proses migrasi yang dapat menyebabkan perubahan energi suatu spesies, penangkapan, musim, bentuk tubuh dan upaya penangkapan serta faktor-faktor alamiah (Fontoura, 2010; Hossain dan Ohnomi, 2010; Ama-abasi, 2007; Mccalahan et al., 2008; Kuriakose, 2017). 

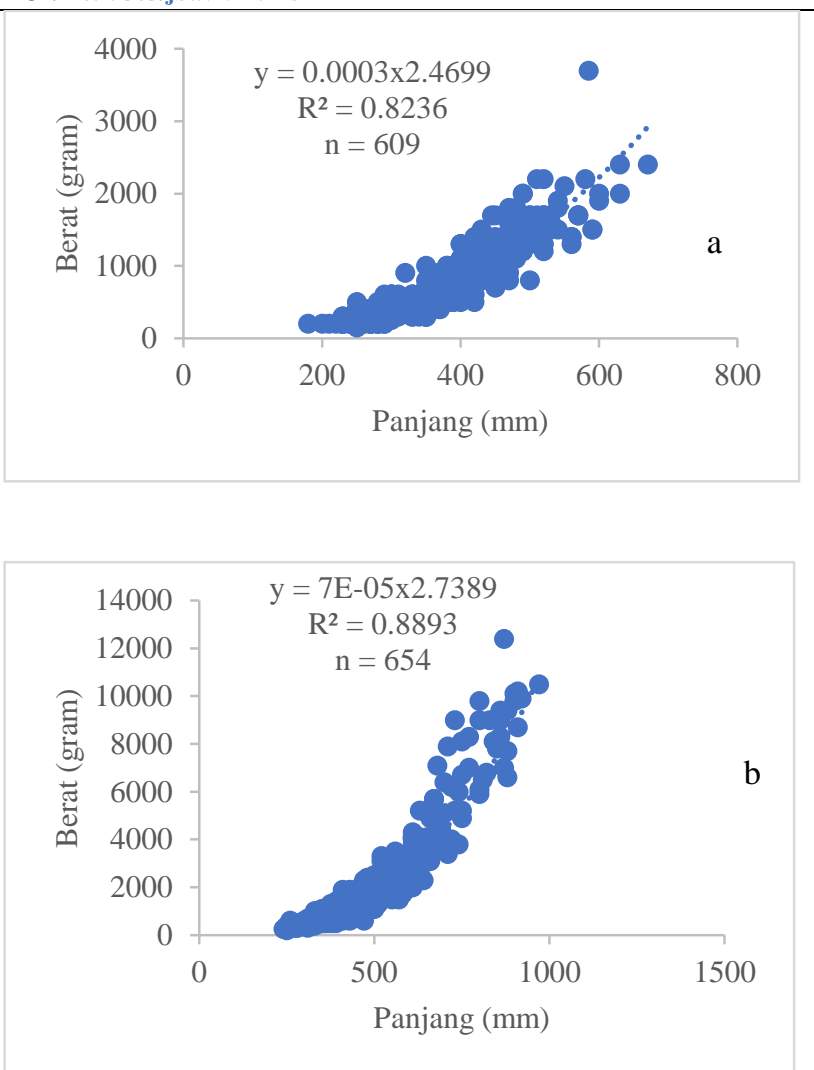

Gambar. 3. Hubungan panjang berat ikan kerapu sunu ( $P$. leopardus) (a); Hubungan panjang berat ikan kerapu sunu (E. fuscoguttatus) (b)

Nilai koefisien kolerasi (r) ikan kerapu sunu ( $P$. leopardus) dan kerapu macan (E. fuscoguttatus) sebesar 0,90 dan 0,94 yang menunjukan kolerasi yang kuat antara panjang dan berat ikan Adaka et al., (2015). Koefisien determinasi $\left(\mathrm{R}^{2}\right)$ 0,8836 menunjukan bahwa panjang ikan kerapu sunu dapat mempengaruhi berat ikan sebesar $88,36 \%$ sedangkan $11,64 \%$ dipengaruhi faktor lain yang tidak diketahui. Pada ikan kerapu macan menghasilkan koefisien determinasi $\left(\mathrm{R}^{2}\right)$ sebesar 0,8893 , berarti bahwa $88,93 \%$ panjang ikan dapat mempengaruhi berat sedangkan $11,07 \%$ dipengaruhi faktor lain yang tidak dapat diketahui. Ndiaye et. al (2015) menjelaskan hubungan panjang berat ikan akan memiliki nilai yang tinggi yang dapat di indikasikan bahwa pertambahan panjang akan diikuti pertambahan berat. Dalam menghitung model regresi tersebut diperoleh standar deviasi dari kedua hasil analisis regresi 0,099.

Setelah membandingkan ukuran panjang ikan kerapu sunu terhadap ukuran maksimum dan ukuran pertama kali memijah, terdapat $72,57 \%$ ikan yang ditangkap merupakan ikan pra-dewasa. Untuk ikan kerapu macan proporsi ini mencapai $43.73 \%$. Aktifitas penangkapan yang menunjukan hasil tangkapan dengan proporsi betina yang lebih tinggi dapat menyebabkan proporsi betina menurun dalam populasi dan mengganggu keseimbangan reproduksi karena keterbatasan jumlah telur (Grandcourt et al., 2005). Hal ini terutama terjadi pada ikan kerapu sunu. Sementara untuk ikan kerapu macan meskipun proporsi betina yang tertangkap belum melebihi angka 50\%, namun perlu ada upaya untuk mencegah semakin tingginya jenis kelamin betina yang tertangkap. Hal ini dikarenakan sifat hermaphrodit protogini yang terjadi pada ikan kerapu diawali dari fase reproduksi betina ke fase jantan (Armswort, 2001).

Alonzo dan Mangel (2004;2005) mengemukakan bahwa dinamika populasi dari spesies ikan protogini sangat peka terhadap mortalitas penangkapan, terutama ikan yang berukuran kecil yang belum mengalami perubahan fase reproduksi. Pada kondisi ini populasi ikan di alam lebih banyak betina yang menyebabkan keterbatasan jantan sehingga proses reproduksi akan terbatas. Selanjutnya Provost et al., (2017) menjelaskan bahwa ikan jantan yang terus mengalami penurunan popuasi melalui penangkapan selektif ukuran dan usia akan mengalami penurunan pada saat masa transisi fase reproduksi.

\section{Pengelolaan Ikan Kerapu}

Tingginya proporsi ikan betina dari kedua spesies hermaphrodit, menunjukan aktifitas perikanan kerapu di perairan Wangi-Wangi dan karang Kaledupa Taman Nasional Wakatobi dapat digolongkan sebagai penangkapan yang tidak berkelanjutan untuk spesies kerapu sunu. Sedangkan spesies kerapu macan masih dapat dikatakan berkelanjutan. Penangkapan yang tidak berkelanjutan tersebut dapat mendorong ikan hermaprodit untuk mengkompensasi kematian jantan yang tinggi secara tidak proporsional (betina mampu mengubah jenis kelamin pada ukuran yang lebih kecil) yang dapat menyebabkan pergeseran ukuran (ikan mengecil) Sanchez (2000) dan Huntsman dan Chaaf (1994). Selain hal tersebut penangkap ikan kerapu yang tidak terkendali dan terjadi pada lokasi-lokasi yang dianggap masyarakat sebagai tempat pemijahan menyebabkan sumber daya ikan yang tinggi tersebut dapat merubah komposisi ukuran ikan menjadi lebih kecil sehingga dapat mempengaruhi hasil produksi (Hurtado et al., 2005; Ehrhardt et al., 2007)

Upaya pengelolaan penangkapan ikan kerapu belum maksimal dilakukan di Taman Nasional Wakatobi. Penangkapan ikan masih dominan proporsi betina (ukuran $<42 \mathrm{~cm}$ ). Sehingga upaya pengelolaan yang harus dilakukan Perairan Taman Nasional Wakatobi perlu memperhatikan pengendalian penggunaan alat tangkap, upaya penangkapan serta sistem buka tutup kawasan penangkapan. Agustina et al., (2018) melaporkan hasil penelitian di Karimunjawa bahwa pegaturan penangkapan ikan sunu perlu dilakukan untuk mengurangi tekanan perikanan dan mendorong pemanfaatan yang berkelanjutan (Chiappone et al., 2000).

Selain itu permintaan pasar dan nilai jual ikan kerapu sunu dan macan pada ukuran 0.5-1 kg (fase reproduksi betina) yang tinggi mempengaruhi upaya penangkapan, sehingga perlu memperhatikan ukuran maksimal yang tertangkap ( $\geq 42 \mathrm{~cm}$ ). Menurut Cheung et al. (2013) Tingginya permintaan pasar dan laju 
penangkapan menyebabkan sumberdaya ikan kerapu rentan yang dapat menimbulkan permasalahan penurunan populasi.

\section{Kesimpulan}

kesimpuan: ditarik

1. Hubungan panjang berat ikan Ikan kerapu sunu ( $P$. leopardus) dan kerapu macan (E. fuscoguttatus) menunjukan pertumbuhan allometrik negative dengan nilai koefisien kolerasi (r) 0,90 dan 0,94 dan koefisien determinasi $\left(\mathrm{R}^{2}\right)$ 88,36\% dan $88,93 \%$.

2. Proporsi ikan kerapu sunu ( $P$. leopardus) yang tertangkap dominan fase reproduksi betina dibandingan dengan ikan kerapu macan ( $E$. fuscoguttatus) yang dominan fase reproduksi jantan, sehingga perlu pengendalian proporsi penangkapan, upaya penangkapan dan penutupan waktu penangkapan ikan kerapu khususnya ikan kerapu sunu.

\section{Ucapan Terima Kasih}

Terima kasih yang sebesar-besarnya kepada Lembaga Pengelola Dana Pendidikan (LPDP) yang telah memberikan dana selama studi, kepada kedua pembimbing dan seluruh pihak yang mendukung penelitian ini kami ucapkan terima kasih yang tak terhingga

\section{Daftar Pustaka}

Adaka G., Ndukwe, E. \& Nlewadim, A. (2015). LengthWeight Relationship Of Some Fish Species In A Tropical Rainforest River In South-East Nigeria. Ransylv. Rev. Syst. Ecol. Res. 17 (2). DOI: 10.1515/Trser-2015-0065.

Adebiyi, F. A. (2013). Length-Frequency Distribution, Length-Weight Relationship and Condition Factor of Sompat Grunt Pomadasys jubelini (Cuvier, 1830) off Lagos Coast, Nigeria. Pertanika J. Trop. Agric. $\quad$ Sci. $\quad 36 \quad$ (4): $337-344$. https://www.researchgate.net/publication/258884 902_Length frequency_distribution_lengthweight_relationship_and_condition_factor_of_so mpat_grunt_Pomadasys_jubelini_Cuvier_1830_o ff_Lagos_coast_Nigeria.

Agustina, S., Natsir, M., Boer M., Purwanto \& Yulianto I. (2018). Parameter populasi kerapu sunu (plectropomus sp.) dan opsi pengelolaannya di perairan karimunjawa. Marine Fisheries. 9 (2): 119-131. DOI: org/10.29244/jmf.9.2.119-131.

Albuquerque, F.S., Peso-Aguiar, M.C., AssuncaoAlbuquerque, M.J.T. \& Galvez, L. (2009). Do climate variables and human density affect
Achatina fulica (Bowditch) (Gastropoda: Pulmonata) shell length, total weight and condition factor. Braz J Biol. 69: 879-885. DOI: org/10.1590/S1519-69842009000400016.

Alonzo, S. H. \& Mangel, M. (2005). Sex-change rules, stock dynamics, and the performance of spawningper-recruit measures in protogynous stocks. U.S. National Marine Fisheries Service Fishery Bulletin. 103:229245.http://aquaticcommons.org/9610/1/alonzo.pdf 2005

Ama-Abasi, D. (2007). A review of length-weight relationship and its parameters in Aquatic species, in Proceedings of the 22nd Annual Conference of the Fisheries Society of Nigeria, Kebbi, Kebbi State, Nigeria, 12th-16th November, 2007. 240244.

http://aquaticcommons.org/23248/2/037_opt.pdf

Armswort, P.R. (2001). Effects of fishing on a protogynous hermaphrodite. Can. J. Fish. Aquat. Sci. 58: 568-578. DOI: 10.1139/cjfas-58

Ayoade, A.A. \& Ikulala A.O.O. (2007). Length weight relationship, condition factor and stomach contents of Hemichromis bimaculatus, Sarotherodon melanotheron and Chromidotilapia guentheri (Perciformes: Cichlidae) in Eleiyele Lake, Southwestern Nigeria. Rev Biol Trop. 55: 969977. http://www.scielo.sa.cr/pdf/rbt/v55n34/art20v55n3-4.pdf

Binohlan, C.B. (2010). Epinephelus fuscoguttatus (Forsskål, 1775). [Terhubung berkala]. http://www.fishbase.org/summary/SpeciesSumma ry.php?genus name $=\mathrm{E}$ ephelus\&speciesname=fuscoguttatus. $\quad\left[\begin{array}{ll}10 & \text { Mei }\end{array}\right.$ 2018].

Blackweel, G.B., Brown, L.M. \& Willis, W.D. (2000). Relative weight (Wr) status and current use in fisheries assessment and management. Reviews in fisheries Science. 8: 1-44. DOI:10.1080/1064126009112916.

Cheung, W., Mitcheson, W.L.Y.S., Braynen, M.T. \& Gittens, L.G. (2013). Are the last remaining Nassau grouper Epinephelus striatus fisheries sustainable? Status quo in the Bahamas. Edangered Species Research Endang Species Res. 20:27-39. DOI:10.3354/esr00472.

Chiappone M., Sluka, R. \& Sealey, K.S. (2000). Groupers (Pisces: Serranidae) in Fished and Protected Areas of The Florida Keys, Bahamas and Northern Caribbean. Marine Ecology Progress Series. 198: 


\section{1-272. https://www.int- \\ res.com/articles/meps/198/m198p261.pdf}

De Robert, A. \& William, K. (2008). Weight-legth relationship in fisheries studies: the standard allometric model should be applied with caution. Transaction of the American Fisheries Society. 137:707-719. DOI:10.1577/T07-124.1.

Ehrhardt, M. N. \& Deleveaux, K. W. V. (2007). The Bahamas Nassau Grouper (Epinephelus striatus) Fishery-two Assessment Methods Applied to a Data Deficient Coastal Population. Fisheries Research. $87: 17-27$.

DOI :org/10.1016/j.fishres.2007.06.020.

Elevati, M. \& Aditya, T.W. (2001). Biologi Kerapu. Departemen Kelautan dan Perikanan. Lampung.

Fontoura, F.N., Jesus, S.A., Larre, G.G. \& Porto, R.J. (2010). Can weight/length relationship predict size at first maturity? A case study with two species of Characidae. Neotropical Ichthyology. 8(4):835840.

http://www.scielo.br/pdf/ni/v8n4/aop1510.pdf

Grandcourt, E.M., Al Abdessalaam, T.Z., Francis, F. \& Al Shamsi. (2005). Population Biology and Assessment of the Orange-spotted grouper, Epinephelus coioides (Hamilton, 1822) in the southern Arabian Gulf. Fisheries Research. 74: 55-68. DOI:10.1016/j.fishres.2005.04.009.

Hossain, M.Y. \& Ohtomi, J. (2010). Growth of the southern rough shrimp Trachysalambria curvirostris (Penaeidae) in Kagoshima Bay, southern Japan. J. Crustacean Biol. 30: 75-82. DOI: $10.1651 / 08-3133.1$.

Huntsman, G.R. \& Schaaf W.E. (1994). Simulation of the Impact of Fishing on Reproduction of a Protogynous Grouper, the Graysby. North American Journal of Fisheries Management. 14:41-52.

http://sedarweb.org/docs/wsupp/S10RD08\%20Si mulFprotogynous\%20Huntsman1994.pdf

Hurtado, E.G., Puelles, R.C.P., Salvador, E., Cota, L., Yanez, A.A.G., Garcia, V.M \& Rosa, R.B. (2005). Historical Biomass, Fishing Mortality, and Recruitment Ternds of The Campeche Bank Red Grouper (Epinephelus morio). Fisheries Research. 71: 267-277. Doi: org/10.1016/j.fishres.2004.09.001

Kuriakose, S. (2017). Estimation of length weight relationship in fishes. ICAR-Central Marine Fisheries Research Institute. 215-220. http://eprints.cmfri.org.in/12178/1/17-
Estimation\%20of\%20length\%20weight\%20relati onship\%20in\%20fishes.pdf

McClanahan, T.R., Hicks, C.C. \& Ddarling, E.S. (2008). Malthusian overfishing and efforts to overcome it on Kenyan coral reefs. Ecological applications. 18(6):1516-1529. DOI :org/10.1890/07-0876.1

Muchlisin, Z.A., M. Musman, M. \& Azizah, M.N.S. (2010). Technical contribution: Length-weight relationships and condition factors of two threatened fishes, Rasbora tawarensis and Poropuntius tawarensis, endemic to Lake Laut Tawar, Aceh Province, Indonesia. J. Appl. Ichthyol. 26:949-953. DOI: 10.1111/j.14390426.2010.01524.x

Ndiaye, W., Diouf, K., Samba, O., Ndiaye, P. \& Panfili, J. 2015. The Length-Weight Relationship and Condition Factor of white grouper (Epinephelus aeneus, Geoffroy Saint Hilaire, 1817) at the southwest coast of Senegal, West Africa. International Journal of Advanced Research. 3 (3):145-153. https://www.researchgate.net/publication/299562 035_The_length-

weight_relationship_and_condition_factor_of_wh ite_grouper_Epinephelus_aeneus_Geoffroy_Saint _Hilaire_1817_at_the_southwest_coast_of_Senegal_West_Africa

Pontoh, O. (2011). Penangkapan ikan dengan bom di daerah terumbuh karang desa Arakan dan Wawontulap. Jurnal perikanan dan Kelautan tropis. 7 https://ejournal.unsrat.ac.id/index.php/JPKT/articl e/view/17

Provost, M. M., Jensen, O.P. \& Berlinsky, D.L (2017). Influence of Size, Age, and Spawning Season on Sex Changein Black Sea Bass. Marine and Coastal Fisheries: Dynamics, Management, and Ecosystem Science. $\quad 9: 126-138$.

DOI: 10.1080/19425120.2016.1274696.

Putri, D.I., Tumulyadi, A. \& Sukandar. (2013). Tingkah laku pemijahan, pembenihan, pembesaran ikan kerapu Tikus (Cromileptes altivelis) di Balai Budidaya Air Payau Situbondo. SPK Student Journal Universitas Brawijaya. I (1): 11-15. https://media.neliti.com/media/publications/18903 0-ID-none.pdf

Ramadhani, A., Muchlisin, Z.A., Sarong, M.A. \& Batubara, A.S. (2017). Length-weight relationships and condition factors of groupers (Serranidae) harvested from Pulo Ace Waters, Aceh Besar Distrrict, Aceh Province. Research paper. $\quad 6 \quad$ (2): $112-121 . \quad$ DOI: 10.13170/depik.6.2.7017. 
Richter, T.J. (2007). Development and evaluation of standard weight equations for bridgelip sucker and largescale sucker. North American Journal of Fisheries Management. 27: 936-939. DOI:10.1577/M06-087.1

Sadovy, Y.J. \& Colin, L.P. (1995). Sexual development and sexuality in the Nassau grouper. Journal of Fish Biology. (46):961-976. DOI:10.1111/j.10958649.1995.tb01401.x

Sadovy, Y.J. (2005). Troubled times for trysting trion : three aggregating groupers in the live reef foodfish trade. SPC Live Reef Fish Information Bulletin. 14: 3-6. doiDOI:10.1.1.610.2878.

Sala, R., Kabera, Y. \& Rumereb, V. (2011). Destructive fishing in Coremap II Area, Raja Ampat. Journal of Indonesia coral reefs. 1(1): 30-40. https://www.academia.edu/29826580/Destructive _fishing.pdf

Sanchez, F.A. (2000). Octopus-red Grouper Interaction in the Exploited Ecosystem Of the Northern Continental Shelf of Yucatan, Mexico. Ecological Modelling. 129:119-129. https://www.researchgate.net/publication/223884 732_Octopusred_grouper_interaction_in_the_exploited_ecosys tem_of_the_northern_continental_shelf_of_Yucat an_Mexico

Sartika, D., Widaningroem, R. \&, Soeparno. (2003). Hubungan panjang-bobot dan faktor kondisi relatif belanak (Liza subviridis) di Laguna Lereng Kabupaten Purworejo. Jurnal Perikanan Universitas Gadjah Mada. 2: 24-31. https://jurnal.ugm.ac.id/jfs/article/view/9035

Tadjuddah, M., Wiryawan, B., Purbayanto, A. \& Wiyono, E.S. (2013). Analisis parameter biologi ikan kerapu (Epinephelus sp.) di Perairan Taman Nasional Wakatobi, Sulawesi Tenggara Indonesia. Marine Fisheries. 4(1). DOI: 10.29244/jmf.4.1.1121.

Theresia, M.S., Pramonowibowo \& Wijayanto, D. (2013). Fisheries bioeconomic analysis of squid (Loligo sp.) in Kendal Coastal Regency. Journal of Fisheries Resources Utilization Management and $\begin{array}{lll}\text { Technology. } & 2 & \text { (3):100-110. }\end{array}$ https://media.neliti.com/media/publications/93605 -ID-analisis-bioekonomi-perikanan-cumicumi.pdf.

Tuya, F., Jerez, S.P. \& Hauron, R. (2006). Populations of inshore serranids across the Canarian Archipelago: Relationships with human pressure and implications for conservation. Biological Conservasition. (128):13-24. DOI: 10.1016/j.biocon.2005.09.012.

Walpole, R. E. (1995). Pengantar Statistika Edisis ke-3. Gramedia Pustaka Utama. Jakarta.

Widodo, M. S. (2006). Deferensiasi gonad/Seks (Hermaprodit protogyni) pada Ikan Kerapu Lumpur (Epinephelus coiodes Hamilton) pada Kisaran Berat Tubuh Yang Berbeda di Perairan Tanjung Luar, Lombok Timur, NTB. Jurnal Protein.13(2):

168-171. http://ejournal.umm.ac.id/index.php/protein/articl e/view/61. 